\title{
Sample size for estimate the average of Passiflora caerulea fruits traits
}

\author{
Dimensionamento amostral para estimação da média de \\ caracteres de frutos de Passiflora caerulea
}

\author{
Cirineu Tolfo Bandeira ${ }^{\mathrm{I}}$ Sabrina Kitina Giordano Fortes ${ }^{\mathrm{II}}$ Marcos Toebe $^{\mathrm{III}}$ \\ Luciano Saifert ${ }^{\mathrm{V}}$ Clevison Luiz Giacobbov ${ }^{\mathrm{V}}$ Leocir José Welter $^{\mathrm{VI}}$
}

\section{ABSTRACT}

The aim of this research was to determine the sample size needed to estimate the average of wild passion fruit (Passiflora caerulea) traits. It was collected randomly, 133, 99 and 133 fruit of wild passion fruit in 30, 21 and 29 plants, located respectively, in the cities of São Borja, Itaqui and Uruguaiana, on the west border of Rio Grande do Sul, Brazil, totaling 365 fruits harvested in 80 plants. In each fruit were measured ten traits: width, length, fruit, skin, and pulp weight, pulp yield, luminosity and tone of skin and pulp. Then, central tendency, dispersion and distribution measures were calculated and the normality of the data checked. After, it was determined the sample size needed to estimate the average for each character, assuming estimation errors equal to $1,2, \ldots$ $10 \%$ of the mean estimate with confidence levels of $95 \%$ and $99 \%$. In wild passion fruit, 12 fruits are sufficient to estimate the mean of luminosity and tone of the skin and pulp, with an estimation error of $5 \%$ of the mean and 95\% confidence, regardless of the evaluation location (São Borja, Itaqui or Uruguaiana). In this same level of accuracy 36 fruits are needed to estimate the width and length, 52 fruits to estimate the pulp yield and 319 fruits for the evaluation of the fruit, skin and pulp weight.

Key words: wild passion fruit, experimental precision, experimental planning.

RESUMO

O objetivo deste trabalho foi determinar o tamanho de amostra necessário para a estimação da média de caracteres de frutos de maracujá-do-mato (Passiflora caerulea). Foram colhidos, aleatoriamente, 133, 99 e 133 frutos de maracujá-do-mato em 30, 21 e 29 plantas localizadas, respectivamente, nos municipios de São Borja, Itaqui e Uruguaiana, na fronteira oeste do estado do
Rio Grande do Sul, Brasil, totalizando 365 frutos colhidos em 80 plantas. Em cada fruto, foram mensurados dez caracteres: largura comprimento, massa do fruto, da casca e da polpa, rendimento de polpa, luminosidade e tonalidade da casca e da polpa. A seguir, foram calculadas medidas de tendência central, de dispersão e de distribuição e verificada a normalidade dos dados. Posteriormente, foi determinado o tamanho de amostra necessário para a estimação da média de cada caractere, assumindo erros de estimação iguais a $1,2, \ldots, 10 \%$ da estimativa da média com graus de confiança de 95\% e 99\%. Em maracujá-do-mato, 12 frutos são suficientes para a estimação da média de luminosidade e tonalidade da casca e da polpa, com erro de estimação de 5\% da média e $95 \%$ de confiança, independentemente do local de avaliação (São Borja, Itaqui ou Uruguaiana). Nesse mesmo nível de precisão, são necessários 36 frutos para a estimação da largura e do comprimento, 52 frutos para a estimação da média de rendimento de polpa e 319 frutos para a avaliação das massas do fruto, da casca e da polpa.

Palavras-chave: Maracujá-do-mato, precisão experimental, planejamento experimental.

\section{INTRODUCTION}

The species Passiflora caerulea belongs to the Passifloraceae family and it is popularly known as wild passion, blue passion flower or red-pulp passion. According to MENDIONDO \& AMELA GARCIA (2006), P. caerulea is the Passifloraceae family species most widely distributed in Latin America in the last century. As

'Programa de Pós-graduação em Agronomia, Universidade Federal de Santa Maria (UFSM), Santa Maria, RS, Brasil.

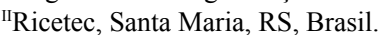

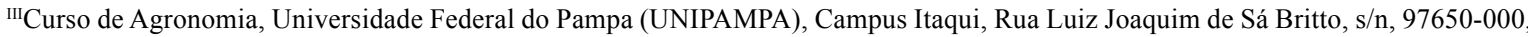
Itaqui, RS, Brasil. E-mail: m.toebe@gmail.com. Corresponding author.

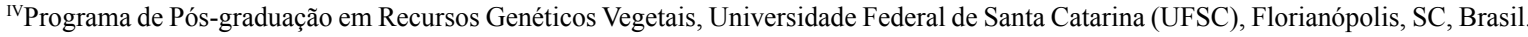

vepartamento de Agronomia, Universidade Federal da Fronteira Sul (UFFS), Campus Chapecó, Chapecó, SC, Brasil.

${ }^{\mathrm{VI}}$ Departamento de Agronomia, Universidade Federal de Santa Catarina, Campus Curitibanos, Curitibanos, SC, Brasil 
stated in DHAWAN et al. (2004), P. caerulea is native from Brazil and the fruit has been used for diuretics, painkillers, and sedatives purposes. The authors also pointed out that this species roots have been used due to its anthelmintic action. As reported by BUSILACCHI et al. (2008), the aerial part of $\boldsymbol{P}$. caerulea is used in the Argentinean pharmaceutical industry and traditional medicine to obtain compounds related to its sedative action. Moreover, FELIÚ-HEMMELMANN et al. (2013) verified that animals that received $\boldsymbol{P}$. caerulea infusion decreased biomarkers associated with physiological stress, proving the phytotherapic action of this plant species. The wild passion plant has also been used as rootstocks of commercial passion fruit plants. In this sense, FUHRMANN et al. (2014) emphasized that P. caerulea demonstrated high degree of resistance to bacterial spot disease caused by Xanthomonas axonopodis pv. passiflorae, allowing it to be used as a disease resistance source.

The correct sample size dimensioning (number of plants and/or number of fruits) is required to have reliability in results obtained in research involving $\boldsymbol{P}$. caerulea and other crops. According to BUSSAB \& MORETTIN (2011), the sample size is proportional to the variability of the data and the desired reliability, being inversely proportional to the a priori error allowed by the researcher. The sample size dimensioning has been studied in several fruits, such as for the evaluation of fruit traits of peach (TOEBE et al., 2011, 2012) and apple cultivars (MIRANDA et al., 2007; TOEBE et al., 2011, 2014), evaluated at harvest and post-harvest. Furthermore, AVANZA et al. (2010) established the sample size for measuring the growth pattern and diameter of orange fruits 'Valencia late' and BARRY et al. (1999) reported the sample size required to estimate the juice content, total soluble solids, acidity, and ratio of orange fruits 'Valencia'.

In Passifloraceae family species, the sample size was determined to characterize the postharvest quality (COELHO et al., 2011) and for the characterization of pulp residues of yellow passion fruit (Passiflora edulis f. flavicarpa) (OLIVEIRA et al., 2011). Further, STORCK et al. (2014) determined the number of plants per plot and the plot number required for the evaluation of yellow passion fruit genotypes. However, sample size dimensioning studies to evaluate wild passion fruits were not found in the literature. Therefore, the aim of this research was to determine the sample size required to estimate the mean of fruit traits of wild passion (Passiflora caerulea).

\section{MATERIALS AND METHODS}

In November 2011, 133, 99, and 133 wild passion fruits (Passiflora caerulea) were randomly harvested in 30,21, and 29 plants located, respectively, in the cities of São Borja, Itaqui, and Uruguaiana, on the west border of Rio Grande do Sul, Brazil, totaling 365 fruits harvested in 80 plants. All evaluated plants were georeferenced and they were located at the coordinates $28^{\circ} 40^{\prime} \mathrm{S}$ and $55^{\circ} 58^{\prime} \mathrm{W}$ of São Borja and $29^{\circ} 33^{\prime} \mathrm{S}$ and $56^{\circ} 51^{\prime} \mathrm{W}$ of Uruguaiana, with altitude ranging from 58.0 to 97.5 meters above the sea level. The 80 plants were randomly chosen and a maximum of five fruits per plant was harvested. These fruits were also randomly chosen at the physiological maturity stage in a single harvest. In some plants, the total number of fruits was less than five because they did not have that number of fruits in physiological maturity stage.

Immediately after harvest, the fruits were transported to the Interdisciplinary Biology Laboratory of the Universidade Federal do Pampa (Unipampa), campus of Itaqui, state of Rio Grande do Sul, located in the geographical coordinates of $29^{\circ} 09^{\prime} S$ and $56^{\circ} 33^{\prime} \mathrm{W}$. Subsequently, it was held measurements of the following traits in each fruit: width and length of the fruit, in $\mathrm{mm}$, utilizing a caliper; fruit, skin, and pulp weight, in grams, utilizing a digital scale; pulp yield in \% obtained from the ratio between pulp weight and total fruit weight; and, luminosity and tone of the skin and pulp, determined by electronic colorimeter with the Minolta CR310 model, as described by TOEBE et al. (2011), wherein two measurements were performed in opposite equatorially areas of each fruit to measure the luminosity and tone of the skin.

For each of the ten traits measured at each location (São Borja, Itaqui, and Uruguaiana), and overall (sum of the evaluated fruits in the three locations), it was calculated the statistics: minimum and maximum values, mean, median, standard deviation, variance, coefficient of variation, kurtosis, skewness and the p-value of normality KolmogorovSmirnov test. Subsequently, the means for each of the ten traits evaluated in the cities of São Borja, Itaqui, and Uruguaiana were compared through the $t$ test for independent samples, adopting $\alpha=5 \%$ of the probability of error and bootstrap resampling with 10,000 simulations.

For each trait evaluated at each location (São Borja, Itaqui, and Uruguaiana) and overall, it was calculated the sample size $(\eta)$ for the semiamplitudes of the confidence interval (estimation 
errors) equal to $1,2, \ldots, 10 \%$ of the estimated mean $(\mathrm{m})$ with degrees of confidence $(1-\alpha)$ of $95 \%$ and $99 \%$. For this, it was used the expression: $\eta=\left(\mathrm{t}^{2}{ }_{\alpha / 2} \cdot \mathrm{s}^{2}\right) /(\text { estimation error })^{2} \quad$ (BUSSAB \& MORETTIN, 2011), being $t_{\alpha / 2}$ the critical value of Student's t-test distribution, whose area on the right is equal to $\alpha / 2$ with (n-1) degrees of freedom, adopting $\alpha=5 \%$ and $\alpha=1 \%$ of the probability of error and an estimated variance of $s^{2}$. Thereafter, $\eta$ was fixed in $133,99,133$, and 365 fruits, respectively, for the evaluation sites of São Borja, Itaqui, Uruguaiana, and in overall. Moreover, the estimation error as a percentage of the estimated mean (m) was calculated for each trait through the expression: estimation error= $\left(100 t_{\alpha / 2} . s\right) /(\sqrt{ } \eta m)$, where $s$ is the estimated standard deviation. Statistical analyzes were performed using the GENES program (CRUZ, 2013) and Microsoft Office Excel ${ }^{\circledR}$ application.

\section{RESULTS AND DISCUSSION}

Overall, the means of the fruits evaluated in Itaqui and Uruguaiana were not statistically different $(\mathrm{P}>0.05)$ in length and fruit, skin, and pulp weights. These values are greater $(\mathrm{P} \leq 0.05)$ than the means verified for these traits in fruits collected in São Borja (Table 1). Pulp yield did not differ between the three locations, as well as the tone of the skin. Luminosity of the skin and pulp presented the greatest mean in fruits collected in Uruguaiana and tone of the pulp exhibited higher means in fruits collected in São Borja. The mean of fruit length $(39.58 \mathrm{~mm} \leq$ mean $\leq 45.18 \mathrm{~mm})$ was lower than the value obtained by SOUSA et al. (2012) in an access of $\boldsymbol{P}$. cincinnata with mean of $50.36 \mathrm{~mm}$. Moreover, the mean of fruit width $(31.54 \mathrm{~mm} \leq$ mean $\leq 35.92 \mathrm{~mm})$ and the mean of fruit weight $(14.25 \mathrm{~g} \leq$ mean $\leq 17.67 \mathrm{~g})$ were also lower than those obtained by SOUSA et al. (2012) of $53.14 \mathrm{~mm}$ and $74.41 \mathrm{~g}$, respectively. However, it has to be emphasized that it was not found data in the literature characterizing fruits of $\boldsymbol{P}$. caerulea that could be compared and discussed with the data of this study.

It was found that four, three and three of the ten evaluated traits presented greater coefficients of variation scores $(\mathrm{CV})$, respectively, in the cities of São Borja, Itaqui, and Uruguaiana (Table 1). These data indicated that there was no tendency of greater or lower variability among evaluation sites and the $\mathrm{CV}$ scores were similar to those obtained with the data from the three sites combined. At the three sites and in the overall, there was wide variability of the coefficient of variation among the ten measured traits and the $\mathrm{CV}$ values increased in the following order: skin luminosity $(3.88 \% \leq \mathrm{CV} \leq 4.20 \%)$; skin tone, luminosity and tone of pulp $(6.60 \% \leq \mathrm{CV} \leq 8.59 \%)$; width and length of fruits $(11.28 \% \leq \mathrm{CV} \leq 15.11 \%)$; pulp yield $(14.69 \% \leq \mathrm{CV} \leq 18.16 \%)$; and fruit, skin, and pulp weight $(34.95 \% \leq \mathrm{CV} \leq 44.94 \%)$. The lowest $\mathrm{CV}$ score of skin luminosity in relation to the pulp luminosity can be explained in terms of the first obtained by averaging two measurements at opposite fruit areas and the second one obtained from a single measurement. These data point to increasing variability and possibly increasing sample size for luminosity and tone of skin and pulp, fruit length and width, and pulp yield measurements, and greater variability between traits related to fruit, pulp, and skin weight.

With the exception of pulp tone assessed in fruits of São Borja and Uruguaiana, all other traits adjusted to the normal distribution $(P \geq 0.13)$, even with some cases statistically significant $(\mathrm{P} \leq 0.05)$ of kurtosis (platykurtic or leptokurtic) and skewness (negative or positive) (Table 1). Considering the three locations combined, the normality of the data was not verified only for skin weight and tone of the skin and pulp, which can be related to the high number of evaluated fruits ( $n=365$ fruits). Thus, it can be inferred that the data are suitable to estimate the sample size by the Student's t-test distribution.

The sample size to estimate the mean of ten traits, with estimation error equal to $1 \%$ of the mean and $95 \%$ of confidence, in fruits from São Borja fluctuated between 59 and 6,128 fruits, respectively for the evaluation of skin luminosity and skin weight (Table 2). In the same precision and confidence level, the sample size ranged among 70 and 7,953 fruits, among 59 and 6,098 fruits, and among 62 and 6,832 fruits, respectively, to evaluate the skin luminosity and pulp weight of fruits deriving from Itaqui, Uruguaiana, and in the overall mean. For the mean estimation of ten traits with estimation error equal to $1 \%$ of the mean and $99 \%$ of confidence, the sample size ranged among 103 and 10,698 fruits, among 122 and 13,936 fruits, among 103 and 10,645 fruits, and among 108 and 11,845 fruits, respectively, to evaluate fruits deriving from São Borja, Itaqui, Uruguaiana, and in the overall mean (Table 3). Sample sizes (number of fruits) were similar among the evaluation sites for the same trait and precision level.

High variability of sample size among traits has also been observed in other fruits. In this sense, a study developed by TOEBE et al. (2014) reported that the sample size to estimate the mean of 
Table 1 - Measurement unit (Un), minimum (Min), maximum (Max), mean, median, standard error (SE), variance (Var), coefficient of variation (CV\%), kurtosis (KT), skewness (SK) and p-value of the Kolmogorov-Smirnov test for ten traits of wild passion fruits (Passiflora caerulea) evaluated in three cities of the west border of Rio Grande do Sul, Brazil.

\begin{tabular}{|c|c|c|c|c|c|c|c|c|c|c|c|}
\hline Fruit trait & Un & Min & Max & Mean $^{(1)}$ & Median & SE & Var & $\mathrm{CV} \%$ & $\mathrm{KT}^{(2)}$ & $\mathrm{SK}^{(3)}$ & p-value \\
\hline \multicolumn{12}{|c|}{ 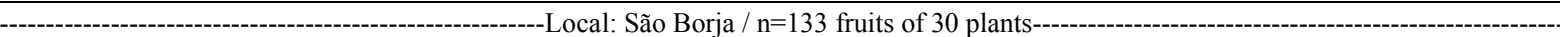 } \\
\hline Width & $\mathrm{mm}$ & 23.88 & 41.55 & $31.54^{\mathrm{c}}$ & 31.35 & 0.33 & 14.70 & 12.16 & $2.86^{\mathrm{ns}}$ & $0.38^{\text {ns }}$ & 0.71 \\
\hline Length & $\mathrm{mm}$ & 29.68 & 49.92 & $39.58^{\mathrm{b}}$ & 39.20 & 0.39 & 19.94 & 11.28 & $2.42^{\mathrm{ns}}$ & $0.11^{\mathrm{ns}}$ & 0.80 \\
\hline Fruit weight & $\mathrm{g}$ & 5.02 & 30.27 & $14.25^{\mathrm{b}}$ & 13.67 & 0.44 & 25.78 & 35.64 & $3.46^{\mathrm{ns}}$ & $0.65^{*}$ & 0.61 \\
\hline Skin weight & $\mathrm{g}$ & 3.21 & 18.37 & $7.21^{\mathrm{b}}$ & 6.60 & 0.25 & 8.14 & 39.57 & $5.60^{*}$ & $1.33^{*}$ & 0.25 \\
\hline Pulp weight & $\mathrm{g}$ & 1.19 & 14.22 & $7.04^{\mathrm{b}}$ & 6.92 & 0.24 & 7.64 & 39.26 & $2.54^{\mathrm{ns}}$ & $0.16^{\mathrm{ns}}$ & 0.97 \\
\hline Pulp yield & $\%$ & 23.52 & 69.30 & $48.89^{\mathrm{a}}$ & 49.03 & 0.77 & 78.85 & 18.16 & $2.87^{\mathrm{ns}}$ & $-0.27^{\mathrm{ns}}$ & 0.74 \\
\hline Skin luminosity & un. & 57.86 & 74.09 & $66.26^{\mathrm{ab}}$ & 66.29 & 0.22 & 6.62 & 3.88 & $4.03^{*}$ & $-0.37^{\mathrm{ns}}$ & 0.59 \\
\hline Skin tone & o & 52.47 & 73.66 & $62.34^{\mathrm{a}}$ & 62.18 & 0.36 & 16.95 & 6.60 & $3.12^{\mathrm{ns}}$ & $0.49^{*}$ & 0.54 \\
\hline Pulp luminosity & un. & 26.87 & 42.08 & $32.34^{\mathrm{b}}$ & 32.03 & 0.20 & 5.41 & 7.19 & $4.78^{*}$ & $0.79^{*}$ & 0.43 \\
\hline Pulp tone & o & 25.88 & 40.33 & $30.42^{\mathrm{a}}$ & 30.10 & 0.23 & 6.83 & 8.59 & $5.32^{*}$ & $1.31^{*}$ & 0.03 \\
\hline \multicolumn{12}{|c|}{ - } \\
\hline Width & $\mathrm{mm}$ & 24.50 & 44.03 & $35.92^{\mathrm{a}}$ & 36.79 & 0.43 & 17.91 & 11.78 & $3.02^{\mathrm{ns}}$ & $-0.66^{*}$ & 0.29 \\
\hline Length & $\mathrm{mm}$ & 29.49 & 63.69 & $45.04^{\mathrm{a}}$ & 45.45 & 0.66 & 43.52 & 14.65 & $3.81^{\mathrm{ns}}$ & $0.23^{\mathrm{ns}}$ & 0.27 \\
\hline Fruit weight & $\mathrm{g}$ & 5.50 & 34.89 & $17.67^{\mathrm{a}}$ & 18.16 & 0.66 & 42.52 & 36.91 & $2.36^{\mathrm{ns}}$ & $-0.01^{\mathrm{ns}}$ & 0.46 \\
\hline Skin weight & $\mathrm{g}$ & 3.36 & 20.54 & $9.11^{\mathrm{a}}$ & 8.84 & 0.32 & 10.14 & 34.95 & $4.20^{*}$ & $0.71^{*}$ & 0.68 \\
\hline Pulp weight & $\mathrm{g}$ & 1.59 & 17.52 & $8.56^{\mathrm{a}}$ & 8.42 & 0.39 & 14.78 & 44.94 & $2.31^{\mathrm{ns}}$ & $0.08^{\mathrm{ns}}$ & 0.64 \\
\hline Pulp yield & $\%$ & 22.30 & 63.26 & $46.85^{\mathrm{a}}$ & 47.16 & 0.82 & 65.97 & 17.34 & $3.57^{\mathrm{ns}}$ & $-0.62^{*}$ & 0.62 \\
\hline Skin luminosity & un. & 58.72 & 73.20 & $65.60^{\mathrm{b}}$ & 65.47 & 0.28 & 7.59 & 4.20 & $2.95^{\mathrm{ns}}$ & $0.04^{\mathrm{ns}}$ & 0.85 \\
\hline Skin tone & o & 53.63 & 76.89 & $62.63^{\mathrm{a}}$ & 61.47 & 0.47 & 21.94 & 7.48 & $2.78^{\text {ns }}$ & $0.46^{\mathrm{ns}}$ & 0.16 \\
\hline Pulp luminosity & un. & 25.81 & 38.67 & $32.54^{\mathrm{ab}}$ & 32.35 & 0.26 & 6.55 & 7.87 & $2.97^{\mathrm{ns}}$ & $0.23^{\text {ns }}$ & 0.36 \\
\hline Pulp tone & o & 25.25 & 35.46 & $29.68^{b}$ & 29.13 & 0.23 & 5.08 & 7.60 & $2.90^{\mathrm{ns}}$ & $0.56^{*}$ & 0.24 \\
\hline \multicolumn{12}{|c|}{--Local: Uruguaiana / $\mathrm{n}=133$ fruits of 29 plants--- } \\
\hline Width & $\mathrm{mm}$ & 22.62 & 43.79 & $34.35^{\mathrm{b}}$ & 33.87 & 0.36 & 17.13 & 12.05 & $3.05^{\mathrm{ns}}$ & $-0.01^{\mathrm{ns}}$ & 0.60 \\
\hline Length & $\mathrm{mm}$ & 33.39 & 59.85 & $45.18^{\mathrm{a}}$ & 43.94 & 0.58 & 44.94 & 14.84 & $2.05^{*}$ & $0.24^{\mathrm{ns}}$ & 0.39 \\
\hline Fruit weight & $\mathrm{g}$ & 3.97 & 32.95 & $16.20^{\mathrm{a}}$ & 14.85 & 0.51 & 34.86 & 36.45 & $2.97^{\mathrm{ns}}$ & $0.43^{*}$ & 0.14 \\
\hline Skin weight & $\mathrm{g}$ & 2.49 & 16.92 & $8.40^{\mathrm{a}}$ & 7.65 & 0.28 & 10.15 & 37.90 & $2.88^{\text {ns }}$ & $0.64^{*}$ & 0.13 \\
\hline Pulp weight & $\mathrm{g}$ & 1.18 & 19.92 & $7.79^{\mathrm{a}}$ & 7.64 & 0.27 & 9.46 & 39.47 & $4.36^{*}$ & $0.51^{*}$ & 0.87 \\
\hline Pulp yield & $\%$ & 27.84 & 62.07 & $47.62^{\mathrm{a}}$ & 47.75 & 0.61 & 48.95 & 14.69 & $2.99^{\mathrm{ns}}$ & $-0.25^{\mathrm{ns}}$ & 0.90 \\
\hline Skin luminosity & un. & 59.84 & 72.88 & $66.52^{\mathrm{a}}$ & 66.54 & 0.22 & 6.65 & 3.88 & $2.84^{\mathrm{ns}}$ & $0.01^{\mathrm{ns}}$ & 0.99 \\
\hline Skin tone & o & 50.58 & 79.76 & $62.76^{\mathrm{a}}$ & 61.70 & 0.44 & 25.17 & 7.99 & $3.95^{*}$ & $0.78^{*}$ & 0.18 \\
\hline Pulp luminosity & un. & 26.26 & 40.55 & $32.95^{\mathrm{a}}$ & 32.60 & 0.23 & 7.23 & 8.16 & $3.22^{\mathrm{ns}}$ & $0.29^{\text {ns }}$ & 0.54 \\
\hline Pulp tone & o & 25.95 & 37.93 & $29.43^{\mathrm{b}}$ & 29.02 & 0.19 & 4.90 & 7.52 & $5.56^{*}$ & $1.36^{*}$ & 0.04 \\
\hline \multicolumn{12}{|c|}{-Data from the three cities $/ \mathrm{n}=365$ fruits of 80 plants } \\
\hline Width & $\mathrm{mm}$ & 22.62 & 44.03 & 33.75 & 33.65 & 0.23 & 19.57 & 13.11 & $2.44^{*}$ & $0.01^{\mathrm{ns}}$ & 0.96 \\
\hline Length & $\mathrm{mm}$ & 29.49 & 63.69 & 43.10 & 42.60 & 0.34 & 42.38 & 15.11 & $2.97^{\mathrm{ns}}$ & $0.47^{*}$ & 0.22 \\
\hline Fruit weight & $\mathrm{g}$ & 3.97 & 34.89 & 15.89 & 14.94 & 0.31 & 35.32 & 37.41 & $2.77^{\mathrm{ns}}$ & $0.42^{*}$ & 0.09 \\
\hline Skin weight & $\mathrm{g}$ & 2.49 & 20.54 & 8.16 & 7.70 & 0.17 & 9.96 & 38.67 & $3.75^{*}$ & $0.85^{*}$ & 0.03 \\
\hline Pulp weight & $\mathrm{g}$ & 1.18 & 19.92 & 7.73 & 7.51 & 0.17 & 10.54 & 42.03 & $3.18^{\mathrm{ns}}$ & $0.37^{*}$ & 0.74 \\
\hline Pulp yield & $\%$ & 22.30 & 69.30 & 47.87 & 48.04 & 0.42 & 64.79 & 16.81 & $3.20^{\mathrm{ns}}$ & $-0.32^{*}$ & 0.88 \\
\hline Skin luminosity & un. & 57.86 & 74.09 & 66.18 & 66.27 & 0.14 & 6.99 & 4.00 & $3.22^{\mathrm{ns}}$ & $-0.13^{\text {ns }}$ & 0.92 \\
\hline Skin tone & o & 50.58 & 79.76 & 62.57 & 61.80 & 0.24 & 21.21 & 7.36 & $3.53^{*}$ & $0.64^{*}$ & 0.03 \\
\hline Pulp luminosity & un. & 25.81 & 42.08 & 32.62 & 32.30 & 0.13 & 6.42 & 7.77 & $3.51^{*}$ & $0.44^{*}$ & 0.08 \\
\hline Pulp tone & o & 25.25 & 40.33 & 29.86 & 29.36 & 0.13 & 5.81 & 8.07 & $5.06^{*}$ & $1.18^{*}$ & 0.01 \\
\hline
\end{tabular}

${ }^{(1)}$ The means of each trait measured in three cities (São Borja, Itaqui and Uruguaiana), followed by the same letter not differ by $\mathrm{t}$ test, at $5 \%$ probability and bootstrap resampling with 10,000 simulations. ${ }^{(2)} *$ Kurtosis differs from three by t test at $5 \%$ probability. ${ }^{\text {ns }}=$ non-significant. (3) * Skewness differs from zero by t test at $5 \%$ probability. ${ }^{\mathrm{ns}}=$ non-significant. 
Table 2 - Sample size (i.e., number of fruits) to estimate the mean of ten traits of wild passion fruits (Passiflora caerulea) with estimation error equal to: $1,2, \ldots, 10 \%$ of estimated mean with $95 \%$ confidence level and semiamplitude of the confidence interval (Error $\%$ ), based on 133, 99, 133 and 365 fruits, respectively, in the cities of São Borja, Itaqui and Uruguaiana and in general.

\begin{tabular}{|c|c|c|c|c|c|c|c|c|c|c|c|}
\hline Fruit trait & $1 \%$ & $2 \%$ & $3 \%$ & $4 \%$ & $5 \%$ & $6 \%$ & $7 \%$ & $8 \%$ & $9 \%$ & $10 \%$ & Error $(\%)$ \\
\hline \multicolumn{12}{|l|}{---------- } \\
\hline Width & 579 & 145 & 65 & 37 & 24 & 17 & 12 & 10 & 8 & 6 & 2.09 \\
\hline Length & 499 & 125 & 56 & 32 & 20 & 14 & 11 & 8 & 7 & 5 & 1.94 \\
\hline Fruit weight & 4.970 & 1.243 & 553 & 311 & 199 & 139 & 102 & 78 & 62 & 50 & 6.12 \\
\hline Skin weight & 6.128 & 1.532 & 681 & 383 & 246 & 171 & 126 & 96 & 76 & 62 & 6.79 \\
\hline Pulp weight & 6.033 & 1.509 & 671 & 378 & 242 & 168 & 124 & 95 & 75 & 61 & 6.74 \\
\hline Pulp yield & 1.292 & 323 & 144 & 81 & 52 & 36 & 27 & 21 & 16 & 13 & 3.12 \\
\hline Skin luminosity & 59 & 15 & 7 & 4 & 3 & 2 & 2 & 1 & 1 & 1 & 0.67 \\
\hline Skin tone & 171 & 43 & 19 & 11 & 7 & 5 & 4 & 3 & 3 & 2 & 1.14 \\
\hline Pulp luminosity & 203 & 51 & 23 & 13 & 9 & 6 & 5 & 4 & 3 & 3 & 1.24 \\
\hline Pulp tone & 289 & 73 & 33 & 19 & 12 & 9 & 6 & 5 & 4 & 3 & 1.48 \\
\hline \multicolumn{12}{|l|}{------------- } \\
\hline Width & 547 & 137 & 61 & 35 & 22 & 16 & 12 & 9 & 7 & 6 & 2.36 \\
\hline Length & 845 & 212 & 94 & 53 & 34 & 24 & 18 & 14 & 11 & 9 & 2.93 \\
\hline Fruit weight & 5.365 & 1.342 & 597 & 336 & 215 & 150 & 110 & 84 & 67 & 54 & 7.37 \\
\hline Skin weight & 4.811 & 1.203 & 535 & 301 & 193 & 134 & 99 & 76 & 60 & 49 & 6.98 \\
\hline Pulp weight & 7.953 & 1.989 & 884 & 498 & 319 & 221 & 163 & 125 & 99 & 80 & 8.97 \\
\hline Pulp yield & 1.184 & 296 & 132 & 74 & 48 & 33 & 25 & 19 & 15 & 12 & 3.46 \\
\hline Skin luminosity & 70 & 18 & 8 & 5 & 3 & 2 & 2 & 2 & 1 & 1 & 0.84 \\
\hline Skin tone & 221 & 56 & 25 & 14 & 9 & 7 & 5 & 4 & 3 & 3 & 1.50 \\
\hline Pulp luminosity & 244 & 61 & 28 & 16 & 10 & 7 & 5 & 4 & 4 & 3 & 1.57 \\
\hline Pulp tone & 228 & 57 & 26 & 15 & 10 & 7 & 5 & 4 & 3 & 3 & 1.52 \\
\hline \multicolumn{12}{|c|}{ 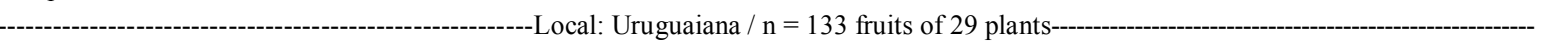 } \\
\hline Width & 569 & 143 & 64 & 36 & 23 & 16 & 12 & 9 & 8 & 6 & 2.07 \\
\hline Length & 862 & 216 & 96 & 54 & 35 & 24 & 18 & 14 & 11 & 9 & 2.55 \\
\hline Fruit weight & 5.199 & 1.300 & 578 & 325 & 208 & 145 & 107 & 82 & 65 & 52 & 6.26 \\
\hline Skin weight & 5.621 & 1.406 & 625 & 352 & 225 & 157 & 115 & 88 & 70 & 57 & 6.51 \\
\hline Pulp weight & 6.098 & 1.525 & 678 & 382 & 244 & 170 & 125 & 96 & 76 & 61 & 6.78 \\
\hline Pulp yield & 845 & 212 & 94 & 53 & 34 & 24 & 18 & 14 & 11 & 9 & 2.53 \\
\hline Skin luminosity & 59 & 15 & 7 & 4 & 3 & 2 & 2 & 1 & 1 & 1 & 0.67 \\
\hline Skin tone & 251 & 63 & 28 & 16 & 11 & 7 & 6 & 4 & 4 & 3 & 1.38 \\
\hline Pulp luminosity & 261 & 66 & 29 & 17 & 11 & 8 & 6 & 5 & 4 & 3 & 1.40 \\
\hline Pulp tone & 222 & 56 & 25 & 14 & 9 & 7 & 5 & 4 & 3 & 3 & 1.30 \\
\hline \multicolumn{12}{|c|}{ 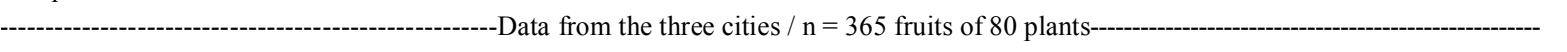 } \\
\hline Width & 665 & 167 & 74 & 42 & 27 & 19 & 14 & 11 & 9 & 7 & 1.35 \\
\hline Length & 883 & 221 & 99 & 56 & 36 & 25 & 19 & 14 & 11 & 9 & 1.56 \\
\hline Fruit weight & 5.412 & 1.353 & 602 & 339 & 217 & 151 & 111 & 85 & 67 & 55 & 3.86 \\
\hline Skin weight & 5.785 & 1.447 & 643 & 362 & 232 & 161 & 119 & 91 & 72 & 58 & 3.99 \\
\hline Pulp weight & 6.832 & 1.708 & 760 & 427 & 274 & 190 & 140 & 107 & 85 & 69 & 4.33 \\
\hline Pulp yield & 1.094 & 274 & 122 & 69 & 44 & 31 & 23 & 18 & 14 & 11 & 1.74 \\
\hline Skin luminosity & 62 & 16 & 7 & 4 & 3 & 2 & 2 & 1 & 1 & 1 & 0.42 \\
\hline Skin tone & 210 & 53 & 24 & 14 & 9 & 6 & 5 & 4 & 3 & 3 & 0.76 \\
\hline Pulp luminosity & 234 & 59 & 26 & 15 & 10 & 7 & 5 & 4 & 3 & 3 & 0.80 \\
\hline Pulp tone & 253 & 64 & 29 & 16 & 11 & 8 & 6 & 4 & 4 & 3 & 0.84 \\
\hline
\end{tabular}


Table 3 - Sample size (i.e., number of fruits) to estimate the mean of ten traits of wild passion fruits (Passiflora caerulea) with estimation error equal to: $1,2, \ldots, 10 \%$ of estimated mean with $99 \%$ confidence level and semiamplitude of the confidence interval (Error \%), based on 133, 99, 133 and 365 fruits, respectively, in the cities of São Borja, Itaqui and Uruguaiana and in general.

\begin{tabular}{|c|c|c|c|c|c|c|c|c|c|c|c|}
\hline Fruit trait & $1 \%$ & $2 \%$ & $3 \%$ & $4 \%$ & $5 \%$ & $6 \%$ & $7 \%$ & $8 \%$ & $9 \%$ & $10 \%$ & Error(\%) \\
\hline \multicolumn{12}{|l|}{------------- } \\
\hline Width & 1.010 & 253 & 113 & 64 & 41 & 29 & 21 & 16 & 13 & 11 & 2.76 \\
\hline Length & 870 & 218 & 97 & 55 & 35 & 25 & 18 & 14 & 11 & 9 & 2.56 \\
\hline Fruit weight & 8.676 & 2.169 & 964 & 543 & 348 & 241 & 178 & 136 & 108 & 87 & 8.08 \\
\hline Skin weight & 10.698 & 2.675 & 1.189 & 669 & 428 & 298 & 219 & 168 & 133 & 107 & 8.97 \\
\hline Pulp weight & 10.531 & 2.633 & 1.171 & 659 & 422 & 293 & 215 & 165 & 131 & 106 & 8.90 \\
\hline Pulp yield & 2.254 & 564 & 251 & 141 & 91 & 63 & 46 & 36 & 28 & 23 & 4.12 \\
\hline Skin luminosity & 103 & 26 & 12 & 7 & 5 & 3 & 3 & 2 & 2 & 2 & 0.88 \\
\hline Skin tone & 298 & 75 & 34 & 19 & 12 & 9 & 7 & 5 & 4 & 3 & 1.50 \\
\hline Pulp luminosity & 354 & 89 & 40 & 23 & 15 & 10 & 8 & 6 & 5 & 4 & 1.64 \\
\hline Pulp tone & 504 & 126 & 56 & 32 & 21 & 14 & 11 & 8 & 7 & 6 & 1.95 \\
\hline \multicolumn{12}{|c|}{ 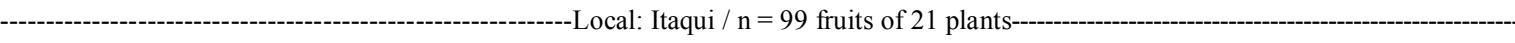 } \\
\hline Width & 959 & 240 & 107 & 60 & 39 & 27 & 20 & 15 & 12 & 10 & 3.12 \\
\hline Length & 1.481 & 371 & 165 & 93 & 60 & 42 & 31 & 24 & 19 & 15 & 3.87 \\
\hline Fruit weight & 9.401 & 2.351 & 1.045 & 588 & 377 & 262 & 192 & 147 & 117 & 95 & 9.75 \\
\hline Skin weight & 8.431 & 2.108 & 937 & 527 & 338 & 235 & 173 & 132 & 105 & 85 & 9.23 \\
\hline Pulp weight & 13.936 & 3.484 & 1.549 & 871 & 558 & 388 & 285 & 218 & 173 & 140 & 11.87 \\
\hline Pulp yield & 2.075 & 519 & 231 & 130 & 83 & 58 & 43 & 33 & 26 & 21 & 4.58 \\
\hline Skin luminosity & 122 & 31 & 14 & 8 & 5 & 4 & 3 & 2 & 2 & 2 & 1.11 \\
\hline Skin tone & 386 & 97 & 43 & 25 & 16 & 11 & 8 & 7 & 5 & 4 & 1.98 \\
\hline Pulp luminosity & 428 & 107 & 48 & 27 & 18 & 12 & 9 & 7 & 6 & 5 & 2.08 \\
\hline Pulp tone & 399 & 100 & 45 & 25 & 16 & 12 & 9 & 7 & 5 & 4 & 2.01 \\
\hline Width & 992 & 248 & 111 & 62 & 40 & 28 & 21 & 16 & 13 & 10 & 2.74 \\
\hline Length & 1.505 & 377 & 168 & 95 & 61 & 42 & 31 & 24 & 19 & 16 & 3.37 \\
\hline Fruit weight & 9.075 & 2.269 & 1.009 & 568 & 363 & 253 & 186 & 142 & 113 & 91 & 8.27 \\
\hline Skin weight & 9.813 & 2.454 & 1.091 & 614 & 393 & 273 & 201 & 154 & 122 & 99 & 8.59 \\
\hline Pulp weight & 10.645 & 2.662 & 1.183 & 666 & 426 & 296 & 218 & 167 & 132 & 107 & 8.95 \\
\hline Pulp yield & 1.475 & 369 & 164 & 93 & 59 & 41 & 31 & 24 & 19 & 15 & 3.33 \\
\hline Skin luminosity & 103 & 26 & 12 & 7 & 5 & 3 & 3 & 2 & 2 & 2 & 0.88 \\
\hline Skin tone & 437 & 110 & 49 & 28 & 18 & 13 & 9 & 7 & 6 & 5 & 1.82 \\
\hline Pulp luminosity & 455 & 114 & 51 & 29 & 19 & 13 & 10 & 8 & 6 & 5 & 1.85 \\
\hline Pulp tone & 387 & 97 & 43 & 25 & 16 & 11 & 8 & 7 & 5 & 4 & 1.71 \\
\hline & & ---Dat & rom the & ee cit & $\mathrm{n}=3$ & fruits $c$ & 0 plan & --- & 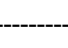 & & \\
\hline Width & 1.152 & 288 & 128 & 72 & 47 & 32 & 24 & 18 & 15 & 12 & 1.78 \\
\hline Length & 1.530 & 383 & 170 & 96 & 62 & 43 & 32 & 24 & 19 & 16 & 2.05 \\
\hline Fruit weight & 9.384 & 2.346 & 1.043 & 587 & 376 & 261 & 192 & 147 & 116 & 94 & 5.08 \\
\hline Skin weight & 10.029 & 2.508 & 1.115 & 627 & 402 & 279 & 205 & 157 & 124 & 101 & 5.25 \\
\hline Pulp weight & 11.845 & 2.962 & 1.317 & 741 & 474 & 330 & 242 & 186 & 147 & 119 & 5.70 \\
\hline Pulp yield & 1.896 & 474 & 211 & 119 & 76 & 53 & 39 & 30 & 24 & 19 & 2.28 \\
\hline Skin luminosity & 108 & 27 & 12 & 7 & 5 & 3 & 3 & 2 & 2 & 2 & 0.55 \\
\hline Skin tone & 364 & 91 & 41 & 23 & 15 & 11 & 8 & 6 & 5 & 4 & 1.00 \\
\hline Pulp luminosity & 405 & 102 & 45 & 26 & 17 & 12 & 9 & 7 & 5 & 5 & 1.06 \\
\hline Pulp tone & 438 & 110 & 49 & 28 & 18 & 13 & 9 & 7 & 6 & 5 & 1.10 \\
\hline
\end{tabular}

Ciência Rural, v.46, n.10, out, 2016. 
traits of apple 'Royal Gala', with estimation error of $1 \%$ of the mean, ranged from 137 to 1,200 fruits at harvest and from 63 to 2,194 fruits after cold storage. Further, in 'Fuji' apples, the authors reported that the sample size varied between 259 and 2,559 fruits at harvest and between 46 and 4,739 fruits after cold storage. In the same precision level, TOEBE et al. (2012) observed that to estimate the mean of traits of peach 'Eldorado', it is necessary to measure 31 to 1,954 fruits at harvest and from 33 to 4,213 fruits after cold storage. For measurement of pulp firmness, luminosity, intensity and tone of the background color of peach epidermis of 'Eragil' and apple 'Royal Gala' under different storage conditions; it was observed sample sizes from 52 to 11,933 fruits and from 111 to 539 fruits, respectively, for peach and apple (TOEBE et al., 2011).

In the present study, high variability of the sample size was observed among traits, requiring 70 , $251,261,289,665,883,1,292,5,412,6,128$, and 7,953 fruits, respectively, to evaluate the skin luminosity, skin tone, pulp luminosity, pulp tone, fruit width, fruit length, pulp yield, fruit weight, skin weight, and pulp weight, with a maximum error of no more than $1 \%$ of the mean and $95 \%$ of confidence, regardless of the evaluation site (Table 2). In general, there was an increase in the sample size in the measurements of luminosity and tone of the skin, luminosity and tone of the pulp, fruit width and length, and pulp yield and greater sample size to measure the weight of fruit, skin, and pulp.

In peach and apple, TOEBE et al. (2011) reported the necessity of larger sample size to assess the pulp firmness when compared to the epidermis background color. In peach 'Eldorado', TOEBE et al. (2012) observed that larger sample sizes are required to estimate the mean of pulp firmness, followed by the mass, ratio, and acidity. In the same study, smaller sample sizes were required to estimate the mean of juice content, length, diameter (greater and smaller), coloring, and total soluble solids. In two apple cultivars, TOEBE et al. (2014) reported that a larger sample size is required to estimate the ethylene production, ratio, respiration, weight, and acidity in relation to the one required for measuring length, pulp firmness, total soluble solids, diameters (greater and smaller), and juice content. Moreover, in orange 'Valencia', BARRY et al. (1999) recommended the measurement of 80 fruits (four fruits/ plant $\times 20$ plants) to determine the juice content, total soluble solids, acidity, and ratio. Furthermore, in orange 'Valencia late', AVANZA et al. (2010) recommended the measurement of 210 fruits ( 30 fruits/plant $\times 7$ plants) to determine the growth pattern and fruit diameter with estimation error of 2 to $3 \%$ of the mean.
It was verified in this research that the measurement of 12 fruits is sufficient to estimate the mean of luminosity and tone of the skin and pulp, regardless the evaluation site with maximum estimation error of $5 \%$ of the mean and $95 \%$ of confidence. In the same precision, 36 fruits are required to estimate the mean of fruit width and length, 52 fruits to estimate mean of pulp yield, and 319 fruits to evaluate the weight of fruit, skin and pulp (Table 2). Further, the estimation error committed with the use of 133 fruits collected in São Borja fluctuated between $0.67 \%$ and $6.79 \%$ to measure the luminosity and weight of the skin, with $95 \%$ of confidence. In Itaqui, the estimation error committed based on 99 evaluated fruits varied from $0.84 \%$ to $8.97 \%$, respectively, for skin luminosity and pulp weight. In Uruguaiana, the estimation error based on 133 evaluated fruits fluctuated between $0.67 \%$ and $6.78 \%$, respectively, for skin luminosity and pulp weight. In general, the estimation error based on 365 evaluated fruits ranged from $0.42 \%$ to $4.33 \%$, respectively, for skin luminosity and pulp weight, with $95 \%$ of confidence.

\section{CONCLUSION}

In wild passion fruit, 12 fruits are sufficient to estimate the mean of luminosity and tone of the skin and pulp, with an estimation error of $5 \%$ of the mean and $95 \%$ confidence, regardless of the evaluation location (São Borja, Itaqui or Uruguaiana). In this same level of accuracy 36 fruits are needed to estimate the width and length, 52 fruits to estimate the pulp yield and 319 fruits for the evaluation of the fruit, skin and pulp weight.

\section{ACKNOWLEDGEMENTS}

To the Universidade Federal do Pampa (UNIPAMPA) for financial and laboratory support.

\section{REFERENCES}

AVANZA, M.M. et al. Optimal sample size for evaluate the growth pattern of 'Valencia late' orange fruit. Revista Brasileira de Fruticultura, v.32, n.4, p.1154-1163, 2010. Available from: <http:// dx.doi.org/10.1590/S0100-29452010005000132>. Accessed: Dec. 29, 2015. doi: 10.1590/S0100-29452010005000132.

BARRY, G.H. et al. Estimating optimal sample size for sweet orange fruit quality experiments. HortScience, v.34, n.3, p.483484, 1999. Available from: <http://hortsci.ashspublications.org/ content/34/3/483.5.abstract>. Accessed: Dec. 29, 2015.

BUSILACCHI, $\mathrm{H}$. et al. Field culture of micropropagated Passiflora caerulea L. histological and chemical studies. Boletin 
Latinoamericano $y$ del Caribe de Plantas Medicinales y Aromaticas, v.7, n.5, p.257-263, 2008. Available from: $<\mathrm{http} / / \mathrm{www}$. redalyc.org/articulo.oa?id=85670504>. Accessed: Dec. 29, 2015.

BUSSAB, W.O.; MORETTIN, P.A. Estatística básica. 7.ed. São Paulo: Saraiva, 2011. 540p.

COELHO, A.A. et al. Sample size for postharvest quality characterization of yellow passion fruits. Revista Ceres, v.58, n.1, p.23-28, 2011. Available from: <http://dx.doi.org/10.1590/S0034737X2011000100004>. Accessed: Dec. 29, 2015. doi: 10.1590/ S0034-737X2011000100004.

CRUZ, C.D. GENES - a software package for analysis in experimental statistics and quantitative genetics. Acta Scientiarum Agronomy, v.35, n.3, p.271-276, 2013. Available from: <http:// dx.doi.org/10.4025/actasciagron.v35i3.21251>. Accessed: Dec. 29, 2015. doi: 10.4025/actasciagron.v35i3.21251.

DHAWAN, K. et al. Passiflora: a review update. Journal of Ethnopharmacology, v.94, n.1, p.1-23, 2004. Available from: $<$ http://dx.doi.org/10.1016/j.jep.2004.02.023>. Accessed: Dec. 29 , 2015. doi: 10.1016/j.jep.2004.02.023.

FELIÚ-HEMMELMANN, K. et al. Melissa officinalis and Passiflora caerulea infusion as physiological stress decreaser. International Journal of Clinical and Experimental Medicine, v.6, n.6, p.444-451, 2013. Available from: <http:// www.ncbi.nlm.nih.gov/pmc/articles/PMC3703115/>. Accessed: Dec. 29,2015

FUHRMANN, E. et al. Reaction of interspecific hybrids of Passiflora spp. to Xanthomonas axonopodis pv. passiflorae. Ciência Rural, v.44, n.8, p.1404-1410, 2014. Available from: $<$ http://dx.doi.org/10.1590/0103-8478cr20121092>. Accessed: Dec. 29, 2015. doi: 10.1590/0103-8478cr20121092.

LÚCIO, A.D. et al. Relations between variables in passion fruit. Ciência Rural, v.43, n.2, p.225-232, 2013. Available from: <http:// dx.doi.org/10.1590/S0103-84782013000200006>. Accessed: Dec. 29, 2015. doi: 10.1590/S0103-84782013000200006.

MENDIONDO, G.M.; AMELA GARCÍA, M.T. Emergence of Passiflora caerulea seeds simulating possible natural destinies. Fruits, v.61, n.4, p.251-258, 2006. Available from: $<$ http://dx.doi. org/10.1051/fruits:2006022>. Accessed: Dec. 29, 2015. doi: 10.1051/fruits:2006022.

MIRANDA, C. et al. Random sample estimates of tree mean for fruit size and colour in apple. Scientia Horticulturae, v.112, n.1, p.33-41, 2007. Available from: $<\mathrm{http}: / / \mathrm{dx}$.doi.org/10.1016/j. scienta.2006.12.006>. Accessed: Dec. 29, 2015.doi: 10.1016/j. scienta.2006.12.006.

OLIVEIRA, E.M.S.de et al. Characterization of yellow passion fruit pulp wastes. Ciência Rural, v.41, n.4, p.725730, 2011. Available from: <http://dx.doi.org/10.1590/S010384782011005000031>. Accessed: Dec. 29, 2015. doi: 10.1590/ S0103-84782011005000031.

SOUSA, L.B.de et al. Characterization and genetic divergence of access of Passiflora edulis and P. cincinnata based on physical and chemical characteristics of fruits. Revista Brasileira de Fruticultura, v.34, n.3, p.832-839, 2012. Available from: $<$ http:// dx.doi.org/10.1590/S0100-29452012000300024>. Accessed: Dec. 29, 2015. doi: 10.1590/S0100-29452012000300024.

STORCK, L. et al. Scaling the number of plants per plot and number of plots per genotype of yellow passion fruit plants. Acta Scientiarum. Agronomy, v.36, n.1, p.73-78, 2014. Available from: $<$ http://dx.doi.org/10.4025/actasciagron.v36i1.17697>. Accessed: Dec. 29, 2015. doi: 10.4025/actasciagron.v36i1.17697.

TOEBE, M. et al. Sample size to evaluate the flesh firmness and epidermis color in peach and apple. Revista Ciência Agronômica, v.42, n.4, p.1026-1035, 2011. Available from: <http://dx.doi. org/10.1590/S1806-66902011000400027>. Accessed: Dec. 29, 2015. doi: 10.1590/S1806-66902011000400027.

TOEBE, M. et al. Sample size to estimate the average peach characters at harvest and after cold storage. Ciência Rural, v.42, n.2, p.209-212, 2012. Available from: <http://www.scielo.br/ pdf/cr/v42n2/a5912cr4891.pdf $>$. Accessed: Dec. 29, 2015. doi: 10.1590/S0103-84782012000200004.

TOEBE, M. et al. Sample size for estimate the average of characters in apples. Ciência Rural, v.44, n.5, p.759-767, 2014. Available from: <http://dx.doi.org/10.1590/S010384782014000500001>. Accessed: Dec. 29, 2015. doi: 10.1590/ S0103-84782014000500001 